\title{
INTEGRASI HUKUM PAJAK DAN ZAKAT DI INDONESIA Telaah terhadap Pemikiran Masdar Farid Mas'udi
}

\author{
Zusiana Elly Triantini \\ UIN Sunan Kalijaga Yogyakarta \\ e-mail: zusiana_triantini@yahoo.com
}

\begin{abstract}
Masdar Farid Mas'udi is famous as an eclectic scholar who produces Islamic thought (ijtihad), which is becomes a subject of conversation among thinkers of Islam in Indonesia. The discourse of zakat and tax integration actually is not something new, but substantially, his thoughts can be used as a consideration of zakat and tax policies in Indonesia, and even become enlightened understanding of Islamic substance in Indonesia. His thoughts on integration of zakat and tax caused controversy and quite diverse questions. This even seems "strange" because he wanted to unite two things that are different substantially and usefulness. However, if we understand his thought more comprehensively both its content and his method of ijtihad, it would seem that his real thinking about tax and zakat unification substantially, can be a problem solution of zakat and tax implementation for Muslims in Indonesia. This paper will present ideas, methods and the formulations of zakat and tax's concept of Masdar Farid Mas'udi.
\end{abstract}

\section{[]}

Masdar Farid Mas'udi terkenal sebagai ulama ekletik yang menghasilkan ijtihad-ijtihad syar'i yang banyak menjadi bahan perbincangan di kalangan pemikir Islam di Indonesia. Wacana integrasi zakat dan pajak memang bukan hal baru, namun secara substansial pemikirannya dapat dijadikan sebagai pertimbangan terhadap kebijakan-kebijakan zakat dan pajak di Indonesia, bahkan menjadi pencerahan pemahaman Islam substansial di Indonesia. Pemikirannya untuk mengintegrasikan zakat dan pajak menimbulkan kontroversi dan pertanyaan yang cukup beragam, bahkan terkesan ganjil karena seolah menyatukan dua hal yang secara substansi dan kegunaannya berbeda. Namun, jika memahami pemikiran Masdar secara menyeluruh baik dari sisi materi maupun metode ijtihadnya, akan terlihat bahwa sejatinya pemikiran Masdar tentang integrasi penyatuan pajak dan zakat secara substansial, dapat menjadi solusi problem pelaksanaan zakat dan pajak bagi umat Islam di Indonesia. Selanjutnya tulisan ini akan memaparkan pemikiran, metode dan formulasi konsep zakat dan pajak Masdar Farid Mas'udi.

Keywords: zakat, pajak, maqāṣid al-sharīah, manajemen zakat

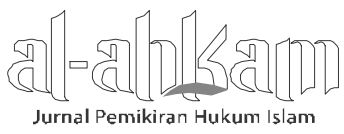




\section{Pendahuluan}

Zakat merupakan salah satu ibadah dalam bidang harta yang mengandung hikmah dan manfaat yang demikian besar dan mulia, baik yang berkaitan dengan orang yang berzakat (muzakki), penerima harta zakat (mustahik), maupun bagi masyarakat keseluruhan. Menurut Yusuf Qardhawi, secara umum terdapat dua tujuan dan ajaran zakat, yaitu untuk kehidupan individu dan untuk kehidupan sosial kemasyarakatan. ${ }^{1}$

Potensi zakat di Indonesia sangat besar, strategis, dan potensial. Sebagai contoh, menurut laporan Budiman,² dana zakat, infaq, dan sadaqah (ZIS) yang dapat diperoleh pada tahun 1990-an di seluruh Indonesia mencapai Rp. 11 miliar. Menurut mantan Menteri Agama RI, Said Agil al-Munawar,3 bahwa potensi dana zakat umat Islam di Indonesia mencapai Rp. 7,5 triliun pertahun. Sedangkan data yang disampaikan oleh Abu Syauki (Direktur Rumah Zakat Indonesia) bahwa potensi dana zakat umat Islam di Indonesia pada tahun 2004 mencapai Rp. 9 triliun. Namun hingga kini yang sudah terkumpul mencapai Rp. 250 miliar atau 2,7\% yang berhasil dihimpun oleh lembaga-lembaga pengelola zakat. Paling tidak angka ini mengindikasikan signifikansi potensi zakat yang luar biasa. ${ }^{4}$

Kondisi demikian ini setali tiga uang dengan kondisi di tingkat lokal. Potensi zakat di DIY misalnya, menurut Ermi Suhasti, dapat mencapai 6 milyar per tahun atau Rp. 500 juta per bulan. Hal ini berdasarkan asumsi sebagai berikut: Berdasarkan sensus penduduk tahun 2000, penduduk DIY berjumlah 3. 107. 919 jiwa di mana 92\% (2.859. 285 jiwa) di antaranya adalah Muslim. Jika saja 1,5\% dari 2.859.285 jiwa tersebut menjadi muzakki aktif maka akan ditemukan sejumlah 14.296 orang. Jika saja 14.296 orang muzakki tersebut rata-rata membayarkan zakatnya Rp. 500.000 per tahun, atau Rp. 41.600 per bulan, maka akan diperoleh angka Rp. 6 miliar tadi. Angka tersebut belum lagi jika ditambah dengan infaq, sadaqah, dan wakaf. Namun pada kenyataannya zakat yang terkumpul pada tahun

1llyas Supena dan Darmuin, Manajemen Zakat(Semarang: Walisongo Press, 2009), h. 16.

2Data sebagaimana dikutip Ermi Suhasti Syafei, “Mengoptimalkan Potensi Zakat” dalam Prosiding Simposium Nasional Ekonomi Islam (Yogyakarta: Pusat Pengkajian dan Pengembangan Ekonomi Islam (P3EI) UII, 2002), h. 574.

3 Ibid.

4 Ibid.

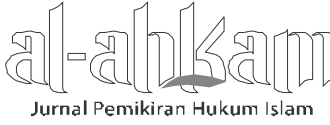


2003 saja baru mencapai sekitar Rp. 500 juta. Jelas, hal ini menunjukkan bahwa potensi zakat tersebut masih belum dapat digali dan diberdayakan secara optimal. ${ }^{5}$

Oleh karena itu, tujuan pendayagunaan zakat pada dasarnya apa saja yang dapat memberikan dan melanggengkan kemaslahatan bagi seluruh masyarakat termasuk usaha-usaha yang mengarah ke situ, maka dapat menjadi bagian dari pendayagunaan zakat dilihat dari sisi maqāșid al-sharīah (tujuan syariat). ${ }^{6}$ Zakat adalah ibadah māliyyah ijtimā'iyyah yang memiliki posisi sangat penting, strategis dan menentukan bagi pembangunan kesejahteraan umat. Ajaran zakat ini memberikan landasan bagi tumbuh dan berkembangnya kekuatan sosial ekonomi umat. Kandungan ajaran zakat ini memiliki dimensi yang luas dan kompleks, bukan saja nilai-nilai ibadah moral spiritual, dan ukhrawi, melainkan juga nilai-nilai ekonomi dan duniawi. ${ }^{7}$

Dalam pergulatan pemikiran hukum ekonomi Islam di Indonesia, integrasi zakat dan pajak merupakan perbincangan baru yang selama satu dekade terakhir menjadi lebih sering diperbincangkan dan dibahas baik dalam kacamata hukum positif maupun hukum Islam. Perdebatan paling krusial terletak pada dasar pengelolaan zakat yang dianggap memiliki unsur-unsur yang berbeda dengan pajak. Beberapa ulama yang mengeluarkan ijtihad syar'inya terkait dengan integrasi zakat dan pajak antara lain Masdar Farid Mas'udi, Didin Hafiddudin, dan Majelis Ulama Indonesia (MUI).

Pembahasan terhadap integrasi zakat dan pajak sebenarnya telah menjadi perdebatan ulama terdahulu hingga sekarang, namun perdebatan tersebut muncul dalam bentuk yang berbeda. Abu Zahrah ${ }^{8}$ misalnya, mengemukakan bahwa pajakpajak itu sampai sekarang tidak memiliki nilai-nilai khusus yang dapat memberikan jaminan sosial. Itulah mula-mula yang menjadi tuntunan zakat. Zakat dapat memenuhi tuntutan pajak, akan tetapi pajak tidak mungkin dapat memenuhi tuntutan zakat, karena pajak tidak menanggulangi kebutuhan fakir miskin yang menuntut untuk dipenuhi.

\footnotetext{
5 Ibid., h. 575.

6 Ilyas Supena dan Darmuin, Manajemen Zakat.., h. 17.

${ }^{7}$ Ibid., h. 21.

${ }^{8}$ Lihat pendapat Abu Zahrah sebagaimana dikutip M. Jamal Doa, Membangun Ekonomi Umat melalui Pengelolaan Zakat Harta, Pengumpulan Zakat dengan Sistem Administrasi perpajakan, Menghindari Pungutan Double Zakat dan Pajak (t.t.p.: Nuansa Madani, 2001).
}

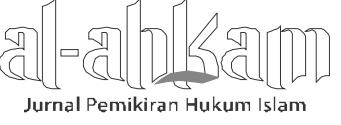

Volume 23, Nomor 2, Oktober 2013 
Zakat dan pajak sebagai sesuatu yang berbeda dan tidak dapat disatukan menurut Abu Zahrah.9 Di negara manapun ketentuan tersebut tetap berlaku selama dia menjadi seorang Muslim. Berbeda dengan pajak, masing-masing negara memiliki ketentuan dan undang-undang sendiri, yang mana satu negara dengan negara lain berbeda. Selain itu, zakat adalah kewajiban yang bersifat tetap dan terus-menerus berlangsung. kewajiban zakat itu akan tetap berjalan selagi umat Islam ada di muka bumi. Kewajiban zakat tidak akan dihapus oleh siapapun, tidak berubah-ubah. Berbeda dengan pajak yang bisa dihapus, misalnya melalui pemutihan, atau berubah menurut kondisi satu negara dan sesuai dengan kebijakan pemerintahnya masing-masing.

Zakat tidak dapat dicukupi oleh pajak. Mereka juga membenarkan kesulitan yang dibebani oleh umat Islam karena dualisme zakat dan pajak, akan tetapi hal ini sesuai dengan ketentuan syari'ah dan akan menjamin kelestarian kewajiban tersebut dan mengekalkan hubungan antar Muslim melalui zakat, sehingga zakat tidak dapat dihapus dan diganti nama pajak dan pajak tak dapat dihilangkan begitu saja.

\section{Biografi dan Pola Pemikiran Masdar Farid Mas'udi}

Masdar Farid Mas'udi lahir di Jombor, Kelurahan Cipete, Kecamatan Cilongok, kabupaten Purwokerto, pada tahun 1954. Dia berasal dari keluarga yang agamis sehingga ketika belajar di Sekolah Dasar, dia melengkapinya dengan ngaji. Sekolah Menengah Pertama ia tempuh di Pesantren Tegalrejo Magelang, sebuah pesantren klasik, selama tiga tahun (1966-1969). Kemudian dia melanjutkan ke pesantren Krapyak, Yogyakarta, langsung masuk ke kelas 6 Tsanawiyah atau kelas 3 Aliyah (1969-1975). Dia melanjutkan ke Institut Agama Islam Negeri Sunan Kalijaga Yogyakarta, Jurusan Syari'ah dan selesai memperoleh gelar (doktorandus) pada tahun 1979.10

Masdar pernah menjadi Direktur P3M (Perhimpunan Pengembangan Pesantren dan Masyarakat) sebuah LSM yang dikenal aktif melakukan aksi-aksi pembaharuan pemikiran Islam dengan pendekatan partisipatoris di kalangan masyarakat pesantren yang justru dikenal "tradisional". Masdar juga aktif sebagai

\footnotetext{
${ }^{9}$ Ibid.

10Mujamil Qomar, NU "Liberal" Dari Tradisionalisme Ahlusunnah ke Universalisme Islam (Bandung: Mizan Pustaka, 2002), h. 198.
}

186 || Volume 23, Nomor 2, Oktober 2013

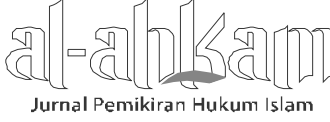


Dosen Islamologi pada STF (Sekolah Tinggi Filsafat) Driyarkara, Jakarta, dan wakil penanggung jawab Pesantren Al-Hamidiyah, Depok, Jakarta. ${ }^{11}$

Masdar Farid Mas'udi adalah seorang cendekiawan yang rajin menulis secara serius dan tajam analisisnya. Dia memiliki dua teori: teori pertama, dimuat dalam buku Agama Keadilan Risalah Zakat (Pajak) dalam Islam yang cukup kontroversial. Teori kedua, dikumpulkan dalam buku Islam dan Hak-Hak Reproduksi Perempuan: Dialog Fiqh Pemberdayaan. Dan terbaru Masdar menulis tentang Pajakitu Zakat yang juga menjadi salah satu buku kontroversial di kalangan sarjana syari'ah. Tulisantulisan lainnya, di samping terdapat pada beberapa buku gabungan para penulis, biasa dimuat di majalah Santri, Aula, Ulumul Qur'an, Studi Islamika, Pesantren, dan aktif menulis pada majalah ibu kota serta dalam beberapa media lainnya.

Masdar adalah seorang pemikir yang mengidolakan 'Umar ibn al-Khațāā. Dialah mazhabnya dengan ciri khas lebih menekankan pemahaman maksud nas daripada bunyi naș. Adapun pemikir yang mempengaruhinya melalui bacaan yang disukai adalah Ali Syari'ati, Muhammad Abduh, Muhammad Iqbal, Azhar Ali, dan Hasan Hanafi. Disamping itu, Kyai Ali Ma'shum menjadi salah seorang yang berpengaruh bagi kebebasan berpikirnya. ${ }^{12}$ Gagasan yang ditelorkan oleh Masdar Farid dalam berbagai pemikirannya tergolong sebagai pola pikir yang ekletik yaitu pola pikir yang berusaha memilih sesuatu yang dianggap terbaik, tidak peduli dari aliran mana pun, filsafat mana pun, dan teori mana pun, asal lebih baik dari yang lain itulah yang dipilih. ${ }^{13}$

Pola pemikiran Masdar Farid Mas'udi tergolong sebagai pola pemikiran yang sangat mengedepankan kemaslahatan umat. Masdar mengungkapkan bahwa "pemilihan gagasan yang dikemukakannya baik berupa konsep, keyakinan maupun doktrin berasal dari berbagai sistem pikiran dalam proses menyusun sistem kita sendiri." ${ }^{\prime 14}$

\footnotetext{
11Masdar Farid Mas'udi, Islam dan Hak-hak Reproduksi Perempuan, Dialog Pemberdayaan (Jakarta: Rajawali Press, 2000).

12Mujamil Qomar, NU “Liberal”..., h. 200.

13 Ibid, h. 251.

${ }^{14}$ Dalam diskursus filasafat, salah satu pengertian eklektisisme adalah "memilih gagasan (konsep, keyakinan, doktrin) dari bermacam sistem pikiran dalam proses menyusun sistem kita sendiri. Dalam bahasan ini, pemikiran yang berpola eklektik tersebut bisa terwujud dengan menyatakan suatu pandangan yang kurang lazim diukur dari kultur orang yang menyatakan pendapat itu sendiri. Dengan begitu, terkadang suatu pemikiran dianggap sangat janggal diungkapkan oleh seseorang, bahkan bisa mengundang resiko yang cukup berat. Ibid.
}

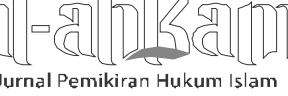


Masdar mengambil kesimpulan bahwa syari'at didasarkan pada kemaslahatan. Dengan kata lain pemikiran ini cenderung terwujud dengan menyatakan suatu pandangan yang kurang lazim diukur dari latar belakang kultur orang yang menyatakan pendapat tersebut, bahkan menjadikan pemikiran Masdar kadangkadang terkesan ganjal dan mempunyai resiko yang sangat berat. ${ }^{15}$

Masdar menyatakan bahwa tolok ukur validitas paham keagamaan bukan dari sudut penalaran murni akal maupun teks ajaran, melainkan suatu kenyataan sejauh mana paham tersebut mampu menjamin tercapainya kebahagiaan bagi manusia, di dunia maupun akhirat.16 Masdar lebih memilih pertimbangan-pertimbangan liberalisasi, progresivitas, adaptasi, dan kemaslahatan sebagai konsep yang paling baik. ${ }^{17}$ Pemikiran Masdar yang demikian menjadikan beliau tergolong sebagai pemikir yang liberal.

Lebih jauh Masdar menerangkan bagaimana konsep qațī dan zannī yang sebenarnya. Konsep qațî menurut beliau adalah ajaran (dalam al-Qur'an dan hadist sahih) yang dikemukakan dalam teks bahasa yang tegas (sharih), sedangkan zhanni merupakan ajaran yang dikemukakan dalam teks bahasa yang tidak tegas, ambigu atau bisa diartikan lebih dari satu pengertian. ${ }^{18}$ Konsep keadilan dan kemaslahatan merupakan ketentuan yang qațî dalam relasi antara manusia yang satu dengan yang lainnnya, sehingga menurutnya, bahasa yang tepat untuk menggambarkan perubahan adalah gerak dan dinamika yang ada. ${ }^{19}$

Masdar menyimpulkan bahwa syari'at didasarkan pada kemaslahatan, dengan kata lain Masdar beranggapan bahwa aturan dalam hukum haruslah tunduk kepada cita kemaslahatan yang ada. ${ }^{20}$ Akan tetapi, dalam konteks ini Masdar tidak memberikan definisi yang jelas mengenai definisi kemaslahatan

Dengan prinsip kemaslahatan dalam merumuskan hukum Islam, menurut Masdar, tidak secara otomatis merubah atau memperbaiki seluruh aturan hukum yang terdapat dalam al-Qur'an dan Sunnah, tetapi terlebih dahulu melakukan

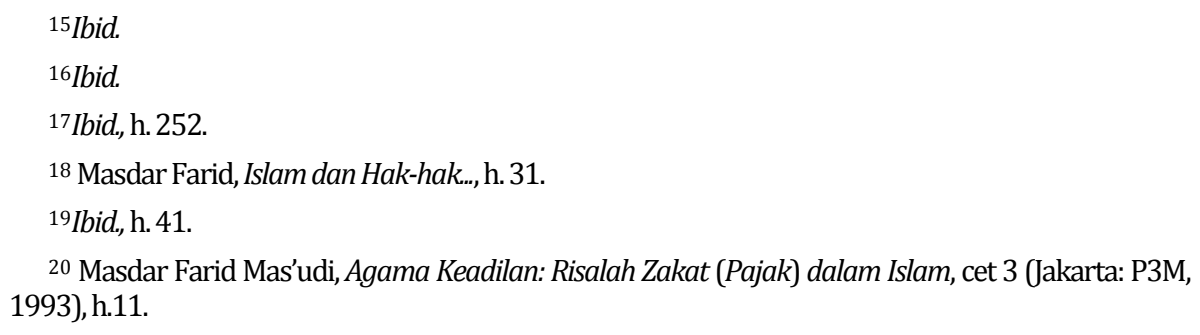


klarifikasi jenis amaliah yang dapat dilakukan hukumnya dengan prinsip kemaslahatan. ${ }^{21}$

Kemaslahatan yang ditawarkan Masdar bersifat individual, subyektif yang menyangkut kepentingan seseorang secara eksistensial bersifat independent, dan terpisah dari kepentingan orang lain maupun kelompok. Dalam kemaslahatan kategori ini karena sifatnya sangat subyektif maka yang berhak menentukan dan sekaligus sebagai hakim adalah pribadi yang bersangkutan. ${ }^{22}$

\section{Pemikiran Masdar Farid Mas'udi Terkait Integrasi Zakat dan Pajak}

Masdar menegaskan bahwa umat Islam yang telah membayar pajak, tidak wajib lagi membayar zakat. Hal itu kalau pajak yang dibayarkan itu telah diniatkan sebagai zakat. Sebab, bagi Masdar, secara batin zakat adalah komitmen spiritual manusia kepada Tuhannya, sedangkan secara lahir, zakat itu merupakan pajak yang merupakan komitmen sosial sesama manusia. Zakat dan pajak, dengan demikian adalah hal yang identik; ibarat zakat adalah ruh, dan pajak sebagai raga yang bersama-sama embodied. Jadi, jika bagi Muslim, pajak berfungsi sebagai zakat, maka bagi non-Muslim pajak itu adalah pajak.

Dalam buku Pajak itu Zakat, ${ }^{23}$ Masdar mengungkapkan bahwa pemisahan lembaga zakat dan pajak adalah suatu hal yang sesat dan menyesatkan karena konsep zakat merupakan konsep pajak, zakat sebagai ruhnya dan pajak sebagai badannya. Oleh karena itu, lebih lanjut Masdar mengatakan bahwa orang yang membayar pajak harus diniati membayar zakat, dengan demikian double tax yang selama ini menjadi permasalahan klasik di masyarakat akan terselesaikan.

Masdar melihat bahwa zakat dan pajak merupakan dua kewajiban yang bisa disatukan meski berangkat dari akar kewajiban yang oleh ulama konvensional dibedakan. Dengan mengabungkan atau menyatukan pajak dan zakat, berarti seorang Muslim yang membayar pajak (dengan spirit dan niat zakat) kepada pemerintah, maka gugurlah (terpenuhi) kewajiban agamanya.

\footnotetext{
${ }^{21}$ Masdar Farid Mas'udi, "Meletakkan Kembali Syari'at” dalam Jurnal Ulumul Qur'an No. 3 Vol. VI, 1995, h. 97.

22 Ibid.

${ }^{23}$ Masdar Farid Mas'udi, Pajak Itu Zakat: Uang Allah untuk Kemaslahatan Rakyat (Bandung: Mizan Media Utama), 2010.
}

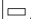

Jurnal Pemikiran Hukum Islam
Volume 23, Nomor 2, Oktober 2013 
Pajak merupakan hal yang hanya menyangkut urusan duniawi, sedangkan zakat bukan saja masalah habl min al-nās (hubungan antara sesama manusia), tetapi juga mengandung muatan habl min Allāh (hubungan antara manusia dengan tuhan). Jika zakat disatukan dengan pajak, maka syari'at dari zakat akan hilang, dan menjadi tidak penting lagi, zakat bukan lagi suatu kewajiban melainkan akan terkesan sebagai suatu anjuran yang tidak bersifat memaksa bagi umat Islam. Agama tidak lagi dipandang sebagai etintas kelembagaan yang terpisah dari negara. Seperti halnya zakat sebagai spirit yang memasukkan ke dalam pajak sebagai badan, demikian pula agama; ia adalah spirit, ruh ilahiyat, yang harus merasuki dan membimbing arah dan jalannya negara sebagai sosok badaniah dan kelembagaannya yang profan.

Dengan demikian, konsep zakat sebagai spirit pajak tidak lain sebagai sebuah konsep spiritualisasi dan transendentalisasi kehidupan negara itu sendiri. Agama yang dianggap sebagai spirit negara adalah keruhanian universal yang bersifat inklusif, yakni komitmen pada keadilan semesta terutama bagi mereka yang lemah dan terpinggirkan. Siapapun mereka, dan apa pun agama dan keyakinan mereka. Oleh karena itu, masuknya spirit zakat ke dalam raga pajak, tidak perlu dipahami sebagai proses Islamisasi yang memojokkan penganut keyakinan atau agama lain. Pesan dasar yang sesungguhnya ingin disampaikan adalah: pertama, hendaknya rakyat tidak lagi membayar pajak semata-mata karena takut sanksi negara yang bersifat lahiriah dan bisa diakali, tetapi justru harus dihayati sebagai panggilan ilahiyyah yang suci. Appeal ini sifatnya personal, langsung pada kesadaran keimanan dalam lubuk hati setiap masyarakat sebagai pribadi-pribadi yang mandiri. Kedua, kepada pihak pemerintah sebagai yang diberi wewenang untuk mengelolanya, hendaknya menyadari bahwa uang pajak yang ada di tangannya adalah amanat Allah yang harus di-tașarruf-kan untuk kemaslahatan segenap warga, terutama yang lemah dan tidak berdaya, apa pun agama dan keyakinanya.

Memahami konsep kelembagaan zakat pada sosok pajak sudah barang tentu membawa implikasi pada kebutuhan rekonstruksi (tajdīd) karena banyak ajaran yang selama ini dianggap baku (qațî) seperti, tentang jenis-jenis kekayaan yang harus dikenakan (māl zakawī), kadar tarif pajak (maqādir al-zakāh), siapa-siapa yang menjadi sasaran alokasi pembelanjaannya (mustahiq al-zakāh), dan sebagainya.

Dengan teori qațî̀ dan zannī-nya, Masdar berusaha meyakinkan bahwa rekonstruksi yang terus menerus itu mungkin, bahkan sejauh tuntutan kemaslahatan 
menghendaki, tidak bisa dihindari. Rekonstruksi yang dikatakannya menjadi tugas dan wewenang lembaga ahl al-hall wa 'l-'aqd (parlemen yang dipilih oleh rakyat dan berpihak pada kepentingan rakyat) itu mengenai, baik pada hasil ijtihad ulama terdahulu, maupun pada ketentuan-ketentuan teknis yang tertera dalam hadishadis Rasulullah SAW.

Dengan tegas Masdar menyatakan bahwa yang harus dipedomani oleh umat Islam dari Rasulullah, sesudah al-Qur'an, bukanlah hadis-hadisnya, melainkan sunnah-nya. Hadis adalah teks penuturan verbal dan formal tentang percikanpercikan perilaku dan pemikiran Rasulullah. Sementara itu, Sunnah adalah perilaku dan way of life dari Rasulullah secara käffah.

Masdar membagi segala sesuatu yang disandarkan kepada Rasululah baik yang qawliyyah maupun yang fi'liyyah pada dua kategori. Pertama, yang berkaitan dengan patokan moralitas atau etika; tentang nilai-nilai kebaikan atau keburukan, tentang yang halal dan yang haram. Yang demikian inilah, yang disebutnya sebagai ketentuan-ketentuan qațiyyah yang bersifat kategoris dan mengikat untuk sepanjang masa. Kedua, hadis Nabi yang berisikan petunjuk praktis-implementatif atau instrumental dari nilai-nilai tersebut di atas. Misalnya, dalam rangka menunaikan kewajiban zakat (pajak) bagi keadilan masyarakatnya, Rasulullah menetapkan atas ternak unta dan sapi, tetapi tidak pada kuda, itik, atau ayam buras. Atas hasil pertanian dikenakan lebih tinggi dibandingkan dengan hasil niaga. Hadis-hadis kategori ini, oleh Masdar disebutnya sebagai hadis-hadis dengan muatan ketentuan-ketentuan yang bersifat zanniyah (hipotesis). Sejauh menyangkut hadis-hadis yang bersifat teknis-implementatif dan instrumental ini, menurut Masdar, tidak bisa tidak harus disikapi secara kritis. Bukan dalam rangka meragukan keabsahan petunjuk Nabi, melainkan dalam rangka memahami signifikansi (dalālah) apa yang dikandungnya dan dengan pertimbangan ketentuanketentuan praktis itu diberikan.

\section{Integrasi Zakat dan Pajak dalam Pandangan Ulama}

Perdebatan tentang integrasi zakat dan pajak sebenarnya telah menjadi perdebatan ulama sejak dahulu, bahkan hingga sekarang. Berangkat dari sebuah wacana, perdebatan ini telah berhasil memicu polemik pemikiran diantara ulama. Abu Zahrah misalnya, mengemukakan bahwa pajak-pajak itu sampai sekarang tidak memiliki nilai-nilai khusus yang dapat memberikan jaminan sosial. Itulah mula-mula yang menjadi tuntunan zakat. Zakat dapat memenuhi tuntutan pajak, 
akan tetapi pajak tidak mungkin dapat memenuhi tuntutan zakat, karena pajak tidak menanggulangi kebutuhan fakir miskin yang menuntut untuk dipenuhi. ${ }^{24}$

Abu Zahrah menyatakan bahwa zakat dan pajak merupakan sesuatu yang berbeda dan tidak dapat disatukan. ${ }^{25}$ Selama seorang masih menjadi Muslim, di negara manapun, ketentuan tersebut tetap berlaku bagi mereka. Berbeda dengan pajak, masing-masing negara memiliki ketentuan dan undang-undang sendiri. Satu negara dengan negara lain berbeda. Selain itu, zakat adalah kewajiban yang bersifat tetap dan terus-menerus berlangsung. Kewajiban zakat itu akan tetap berjalan selagi umat Islam ada di muka bumi. Kewajiban zakat tidak akan dapat dihapus oleh siapapun dan tidak berubah-ubah. Zakat tidak dapat dicukupi oleh pajak. Dualisme zakat dan pajak bagi beberapa kalangan dianggap membebani umat Islam, akan tetapi ketentuan zakat merupakan ketentuan syari'ah dan akan menjamin kelestarian kewajiban tersebut dan mengekalkan hubungan antar Muslim melalui zakat, sehingga zakat tidak dapat dihapus dan diganti nama pajak, demikian juga pajak tidak dapat dihilangkan begitu saja.

Perbedaan pendapat terjadi di kalangan ulama tentang integrasi zakat dan pajak. MUI, sebuah lembaga ulama yang mempertahankan disparitas zakat dan pajak menegaskan bahwa umat Islam di samping berkewajiban membayar zakat, juga berkewajiban membayar pajak. Alasannya, zakat adalah kewajiban yang harus ditunaikan atas dasar naș al-Qur'an dan Sunnah, sedangkan pajak adalah kewajiban yang harus ditunaikan atas dasar ketetapan pemerintah yang dibenarkan oleh ajaran Islam berdasarkan prinsip kemaslahatan umum. Zakat merupakan kewajiban agama, sedangkan pajak merupakan kewajiban sebagai warga negara. Jadi, umat Islam diwajibkan menunaikan zakat sebagai realisasi perintah agama, sementara pajak wajib pula mereka lunasi sebagai realisasi ketaatan warga negara kepada negara bangsa. Dengan demikian, pendapat MUI ini melihat pembayaran zakat maupun pembayaran pajak adalah dua hal yang berbeda, tapi sama-sama bersifat imperatif, dan karenanya wajib diamalkan kedua-duanya oleh umat Islam secara terpisah.

\footnotetext{
24Pendapat Abu Zahrah sebagaimana dikutip M. Jamal Doa, Membangun Ekonomi Umat melalui Pengelolaan Zakat Harta. Lihat pula Didin Hafiduddin, "Sinergi Zakat dengan Pajak dalam Menyejahterakan Umat".

${ }^{25}$ Didin Hafiduddin, "Sinergi Zakat dengan Pajak dalam Menyejahterakan Umat", makalah pada seminar di Dirjen Pajak, Jakarta 19 Agustus 2011.
} 
Memang, jika pendapat ini diamalkan akan menghasilkan input dana yang maksimal. Hanya saja misalnya, bagi sebagian besar umat Islam, adanya dua kewajiban itu sungguh merupakan beban yang sangat memberatkan. Akibatnya, berhubung zakat ditunaikan berdasarkan iman atau kesukarelaan, disamping tidak ada kontrol dan pemberian sanksi bagi pelanggarnya, maka pembayarannya pun tidak jarang terabaikan atau tergantung pada tingkat ketaqwaan seseorang. Dalam hal ini, zakat kalah pengaruh oleh pajak. Hal inilah yang seringkali menjadi kendala utama dalam meningkatkan jumlah penerimaan zakat pada lembagalembaga pengumpul zakat. Kenyataan tersebut berbeda sekali dengan pajak, yang karena didorong secara imperatif oleh negara, pembayarannya selalu dilunasi setiap jatuh tempo. Bagi yang terlambat, ditegur, bagi yang membayar tepat pada waktunya, diberikan diskon khusus atau diberi penghargaan. Di negara Barat, bagi orang yang tidak membayar pajak atau menggelapkan pajak, dapat dihukum pidana dengan hukuman yang cukup berat.

Lebih jauh Didin Hafiduddin mengungkapkan ada beberapa alasan dan kemungkinan zakat dianggap sebagai pengurang pajak, karena dalam pembahasan amandemen UU No. 38 Tahun 1999 tentang Pengelolaan Zakat, masalah ini dianggap yang paling krusial. Perdebatan mengenai hal ini mengarah pada dua arus utama perbedaan pendapat. Pertama, ada kelompok yang berpandangan bahwa kebijakan zakat sebagai penghasilan bruto wajib pajak (tax deductible), sebagaimana yang dianut selama ini, merupakan pilihan yang paling tepat. Kedua, ada yang berpandangan bahwa kebijakan zakat sebagai pengurang pajak secara langsung (tax credit) merupakan langkah strategis dalam upaya menggali potensi zakat, sekaligus mengintegrasikannya secara lebih mendalam dalam perekonomian nasional. Paling tidak, ada dua argumentasi dasar yang memperkuat pernyataan kelompok kedua ini. ${ }^{26}$ Argumentasi pertama, dari perspektif keuangan negara. Ketika ada proses sinergi dan integrasi zakat pada kebijakan fiskal, maka akan ada sejumlah manfaat yang akan didapat, yaitu, perluasan basis muzakki dan wajib pajak, serta membantu meringankan beban APBN dalam hal anggaran pengentasan kemiskinan. Melalui koordinasi yang baik antara otoritas zakat dengan otoritas pajak, maka identifikasi wajib zakat (muzakki) dan wajib pajak akan semakin luas, sehingga diharapkan pendapatan pajak dan zakat akan semakin meningkat. Hal ini secara empirik telah dibuktikan oleh Malaysia, di mana pendapatan zakat dan pajak justru semakin meningkat pasca pemberlakukan

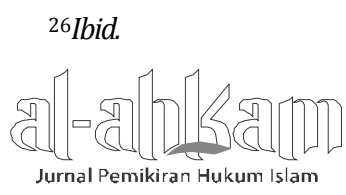

Volume 23, Nomor 2, Oktober 2013 
kebijakan zakat sebagai kredit pajak. Tidak ada trade off antara penerimaan pajak dengan zakat.

Argumen kedua, dari perspektif distribusi ekonomi. Instrumen zakat ini diyakini akan menjadi alat redistribusi ekonomi yang efektif, di mana ia menjamin aliran kekayaan dari kelompok kaya kepada kelompok miskin. Sehingga, economic growth with equity yang selama ini didengung-dengungkan akan dapat terealisir dengan baik di lapangan. Secara ekonomi, aliran kekayaan dalam zakat ini akan mampu memberikan multiplier effect yang sangat besar. Pertumbuhan ekonomi akan terdongkrak lebih tinggi lagi. Hal tersebut dikarenakan keberadaan zakat akan menggenjot konsumsi dan invenstasi, di mana yang menjadi target utamanya

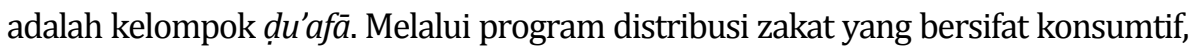
kebutuhan primer mustahik pada jangka pendek akan terpenuhi. Sedangkan melalui program zakat produktif, rumah tangga mustahik pada jangka panjang akan memiliki daya tahan ekonomi yang lebih baik.

\section{Analisis Hukum Positif dan Hukum Islam}

Upaya untuk memperbaiki dan meningkatkan pola pengembangan manajemen zakat dan pajak telah dilakukan berkali-kali oleh pemerintah. Dimulai dari dikeluarkannya UU No. 38 Tahun 1999 tentang Pengelolaan Zakat hingga direvisinya undang-undang tersebut menjadi UU No. 23 Tahun 2011 tentang Pengelolaan Zakat. Bahkan upaya regulasi untuk menghilangkan beban ganda kaum Muslim juga dilakukan dengan peraturan zakat sebagai pengurang pajak sebagaimana diatur dalam PP No. 60 Tahun 2010 tentang Zakat atau Sumbangan Keagamaan yang Sifatnya Wajib yang Boleh Dikurangkan dari Penghasilan Bruto dan Peraturan Direktur Jenderal Pajak Nomor PER-15/PJ/2012 yang berlaku sejak tanggal 11 Juni 2012 yang sebelumnya diatur dengan Peraturan Direktur Jenderal Pajak No. PER- 33/PJ/2011.

Pada tataran realitas, penerapan atau pemberlakuan undang-undang atau peraturan terkait dengan zakat dan pajak belum berjalan secara maksimal karena kendala beberapa hal yang terjadi di masyarakat antara lain: 1) masyarakat masih menggunakan konsep konvensional terkait pajak dan zakat; 2) kurangnya sosialisasi yang dilakukan oleh pemerintah terkait undang-undang dan peraturan terkait zakat dan pajak yang telah ada; 3) wacana integrasi zakat dan pajak masih menjadi perdebatan di kalangan ulama; 4) regulasi pemerintah yang kurang menyentuh banyak komponen yang ada dalam zakat dan pajak. 
Benturan pendapat ulama terkait integrasi zakat dan pajak menjadi salah satu penyebab tidak berjalannya konsep tersebut secara maksimal. Sebagian masyarakat yang masih mempercayai ulama dengan pola pikir konvensional tentu akan menolak adanya regulasi pengintegrasian zakat dan pajak dengan pola zakat sebagai pengurang pajak tersebut. Persolan ini seharusnya disikapi pemerintah dengan mengkaji integrasi zakat dan pajak dalam konteks hukum Islam sehingga ditemukan pengertian komprehensif dan pasti serta dapat dijadikan hujjah dalam ilmu zakat modern. Tentu pemaknaan ulang tersebut juga harus diiringi dengan sosialisasi atas pemaknaan ulang tersebut dan dilanjutkan dengan pembuatan regulasi yang menyangkut keseluruhan komponen dalam zakat dan pajak, termasuk di dalamnya tentang nisab, kadar dan hawl yang ada dalam zakat.

Langkah ini sebenarnya telah dilakukan dengan dikeluarkannya Kompilasi Hukum Ekonomi Syari'ah (KHES) yang disusun dalam rangka memenuhi kebutuhan pedoman bagi para hakim mengenai hukum ekonomi menurut prinsip syari'at $^{27}$ Dalam Kompilasi Hukum Ekonomi Syari'ah, zakat dimasukkan dalam pembahasan bab zakat dan infak, tepatnya dibahas pada Pasal 668-684. Pembahasan tersebut meliputi, ketentuan umum zakat, harta yang wajib dizakati dan pendistribusian zakat. Di dalam KHES juga di bahas secara khusus tentang zakat profesi dan zakat barang tambang.

Zakat dalam KHES disebut sebagai harta yang wajib disisihkan oleh seorang Muslim atau lembaga yang dimiliki oleh Muslim untuk diberikan kepada yang berhak menerimanya. ${ }^{28}$ Zakat tersebut mencakup zakat emas dan perak, zakat profesi, zakat pertanian, zakat perdagangan dan zakat fitrah. KHES telah cukup detail menyebutkan beberapa harta yang wajib dizakati. Hampir di setiap harta yang berkembang dalam bentuk apapun telah melekat zakat yang wajib dibayarkan oleh umat Islam sebagai tanggung jawab sosial atau kewajiban ibadah sosial yang merupakan salah satu wujud keimanan seseorang.

Jika dalam ketentuan zakat secara konvensional hanya menyebutkan secara garis besar seperti halnya zakat ternak, zakat perdagangan, zakat pertanian dan sebagainya, dalam KHES ini sudah secara detail terdapat ketentuan tentang jenis ternak, jenis perdagangan dan jenis pertanian yang harus dibayarkan zakatnya. Hal ini telah mengurangi banyaknya pertanyaan yang hadir dari masyarakat Muslim

\footnotetext{
${ }^{27}$ Kompilasi Hukum Ekonomi Syari'ah (KHES), h. xi.

${ }^{28}$ Ibid, h 207.
}

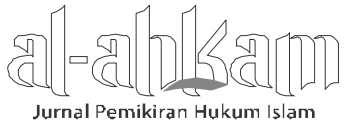


ketika mengupas tentang zakat. KHES juga secara detail emmuat aturan-aturan yang terkait dengan ketentuan umum zakat (Pasal 669), mustahik zakat (Pasal 682), amil zakat dalam hal ini disebut negara (Pasal 683), serta sanksi dan denda terkait zakat (Pasal 683). ${ }^{29}$ Meskipun ketentuan tersebut belum mengupas tentang ketentuan sanksi bagi amil atau pengelola zakat, sebagai bagian dari perkembangan relasi hukum Islam dan hukum positif, KHES dapat dijadikan sebagai acuan dalam penerapan zakat di Indonesia.

KHES yang disusun oleh para pakar Hukum Islam dan para pakar Ekonomi Syari'ah bersama tim Konsultan dan anggota Pokja Perdata Agama Makamah Agung RI beserta Tim Penyusun KHES merupakan salah satu produk hukum yang perlu mendapatkan apresiasi positif di tengah ketidaktegasan negara terkait dengan pelaksanaan hukum perekonomian di Indonesia.

Zakat sebagai salah satu sumber pendapatan negara akan menjadi salah satu pilar penegakan ekonomi dan pemberantasan kemiskinan jika penerapannya dilakukan secara profesional yaitu pemberian atau pembagian zakat didasarkan pada data yang ada dan bukan hanya berdasar pada pengetahuan sepintas tentang kondisi masyarakat setempat. Pelaksanaan ketentuan zakat dalam KHES tentu harus pula didukung oleh undang-undang lain yang mengatur tentang pengelolaan, pendistribusian dan segala sesuatu yang terkait dengan zakat sebagaimana telah diupayakan keberadaannya selama satu dasawarsa terakhir.

Berbagai upaya maksimalisasi zakat dan peringanan beban ganda bagi Muslim di Indonesia telah dilakukan, namun tidak salah jika kita belajar dari negara lain seperti Malaysia misalnya yang menerapkan sumbangan keagamaan sebagai pengurang pajak. Selain Malaysia, berbagai negara juga menerapkan kebijakan serupa, yaitu donasi sosial sebagai pengurang pajak langsung. Hal ini memberi peluang pemberian insentif pajak bagi para muzakki, dan bukan merupakan hal yang "luar biasa". Sebagai contoh, di Puerto Rico, jumlah donasi sosial yang dapat diajukan sebagai kredit pajak adalah berkisar pada angka tiga persen (batas bawah) hingga 15\% (batas atas). Jika seseorang mendonasikan pendapatannya dalam range tersebut, maka insentif pajak yang diberikan adalah sebesar sepertiga (33,33 persen) dari total donasinya. Misalnya seseorang memiliki pendapatan Rp. 100 juta/tahun, dan ia menyumbangkan Rp. 15 juta (batas atas klaim, 15\%) untuk keperluan sosial, maka angka yang dapat diklaim sebagai tax rebate adalah

\footnotetext{
29 Ibid., h $206-212$.
} 
sepertiga dari Rp. 15 juta, yaitu Rp. 5 juta. Sehingga jika ia memiliki kewajiban pajak (misalnya) Rp. 22 juta, maka ia tinggal membayar Rp. 17 juta. ${ }^{30}$

Sebuah studi yang dilakukan oleh Boris, Cordes dan Soto sebagaimana dikutip Didin,31 bahwa penerimaan donasi sosial di Puerto Rico akan meningkat signifikan jika batas bawah jumlah donasi yang dapat diklaim sebagai kredit pajak, dikurangi hingga satu persen atau dihilangkan sama sekali, dan batas atasnya dinaikkan maksimal 50\% dari total pendapatan seseorang. Dari simulasi yang dilakukannya, kebijakan ini akan mendongkrak penerimaan donasi sosial, jauh melebihi potential loss dari pendapatan pajak negara. Dengan kata lain, nilai donasi sosial ini akan lebih besar dari jumlah pajak yang hilang akibat dikorupsi dan kebocoran lainnya.

Manfaat kedua, keberadaan zakat akan sangat membantu meringankan beban APBN dalam pengentasan kemiskinan. Dengan anggaran Rp. 86 triliun yang dialokasikan untuk pengentasan kemiskinan tahun 2011, setiap orang miskin akan menerima bantuan rata-rata Rp. 2.77 juta pertahun atau Rp. 230 ribu/bulan. Jika zakat bisa direalisasikan sebesar Rp. 100 triliun saja, atau senilai 46.08\% dari total potensi zakat yang mencapai angka Rp. 217 triliun, maka akan ada tambahan dana Rp. 3.22 juta pertahun bagi setiap orang miskin, atau Rp. 268 ribu perbulan. Tinggal memperkuat koordinasi program pengentasan kemiskinan antara kementerian terkait dengan BAZ dan LAZ. Dengan demikian tujuan negara untuk mengentaskan kemiskinan akan dapat terakselerasi dengan baik. $^{32}$

Secara empirik, terbukti bahwa zakat memberikan dampak yang positif. Berdasarkan catatan dan analisa BAZNAS, jumlah mustahik yang mendapat bantuan zakat pada tahun 2010 mencapai angka 2.8 juta jiwa. Jika diprosentasikan, angka ini equivalent dengan 9.03\% dari keseluruhan penduduk miskin di tanah air. Kemudian dalam berbagai riset yang telah dilakukan, seperti Beik (2010), IMZ (2010), Tsani dan Beik (2010) terbukti bahwa dana zakat yang dikelola oleh BAZ dan LAZ mampu mengurangi jumlah kemiskinan mustahik, tingkat kedalaman mustahik, dan tingkat keparahan mustahik.

Sebagai contoh, di wilayah Jabodetabek, jumlah rumah tangga mustahik yang dapat dibebaskan dari kemiskinan mencapai angkat 10,79\% pada tahun 2010.

\footnotetext{
30Didin Hafiduddin, "Sinergi Zakat dengan Pajak dalam Menyejahterakan Umat".

31 Ibid,

${ }^{32}$ Ibid,
}

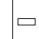

Jurnal Pemikiran Hukum Islam 
Adapun di Kabupaten Garut, angka ini mencapai 21,40\%, lebih tinggi dibandingkan dengan kabupaten Lampung Selatan (18,60\%), maupun kota Kota Bogor (8,77\%). Ini menunjukkan bahwa pengelolaan zakat melalui institusi 'amil yang amanah dan terpercaya, memiliki dampak positif terhadap penurunan angka kemiskinan. Untuk tahun 2011 ini, IMZ memprediksi bahwa jumlah rumah tangga mustahik yang dapat dientaskan dari garis kemiskinan mencapai angka 13,88\%.33

\section{Kesimpulan}

Integrasi zakat dan pajak sangat diperkulan dan merupakan langkah maju dalam transformasi hukum positif dan hukum Islam di Indonesia karena secara kuantitatif penduduk bangsa Indonesia mayoritas beragama Islam. Fakta dan legitimasi ini, memberikan peluang yang cukup besar untuk penerapan hukum Islam secara komprehensif. Namun tentu dengan catatan bahwa pengintegrasiannya menggunakan manajemen yang baik dan proporsional.

Pemikiran Masdar Farid dalam beberapa hal merupakan wacana yang tidak baru, namun secara substansial dapat dijadikan sebagai pertimbangan terhadap kebijakan-kebijakan zakat dan pajak di Indonesia, sehingga masyarakat Muslim Indonesia dapat melaksanakan ajaran ideologinya dengan baik sekaligus menjadi warga negara yang baik pula. Selain itu, dengan pertimbangan maslahat dan pendekatan siyāsah shar'iyyah, integrasi pengelolaan zakat dan pajak oleh negara, termasuk penerapan sanksi bagi pihak-pihak yang terkait yang tidak taat hukum menjadi urgen adanya.

Integrasi pengelolaan zakat dan pajak oleh pemerintah ini adalah sangat logis karena adanya beberapa pertimbangan, di antaranya adalah: a) untuk menjamin kepastian dan disiplin pembayar pajak dan zakat; b) menjaga perasaan rendah diri para mustahiq zakat apabila langsung menerima haknya dari para wajib zakat; c) untuk mencapai efesiensi, efektivitas, dan sasaran yang tepat dalam penggunaan harta zakat menurut skala prioritas yang ada pada suatu tempat; d) untuk memperlihatkan syi'ar Islam dalam semangat penyelenggaraan negara dan pemerintahan yang Islami. e) nilai transendental zakat bisa menjadi pegangan moral pengelola zakat dan pajak sehingga meminimalisir terjadinya korupsi dalam pengelolaan dan nepotisme dalam pendistribusian. f) meningkatkan nilai keimanan masyarakat.

\footnotetext{
${ }^{3}$ I $\mathrm{bid}$
}

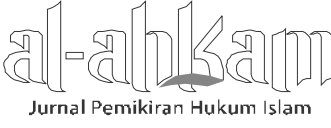


Pendayagunaan zakat dan pajak akan berjalan maksimal karena unsur keadilan ekonomi dan pembangunan di masyarakat dikendalilan melalui satu pintu dan didorong oleh kebutuhan untuk segera dibentuk Dirjen pajak dan zakat menjadi semakin mendesak. Dirjen ini akan memerankan fungsi regulator dan pengawas, sekaligus penentu kebijakan pengelolaan pajak dan zakat di Indonesia. Orientasi dari lembaga ini adalah mengarahkan agar pajak dan zakat dapat dimaksimalkan dalam membantu pengentasan kemiskinan, pencapaian organisasi pajak dan zakat yang profesional dan akuntabel, serta integrasi dan sinergi seluruh organisasi pajak dan zakat di bawah satu payung kebijakan nasional.[a]

\section{DAFTAR PUSTAKA}

Ali, Muhammad Daud, Hukum Islam: Pengantar Ilmu Hukum dan Tata Hukum Islam di Indonesia, Jakarta: Raja Grafindo Persada, 1999.

Altman, Andrew, Critical Legal Studies: a Liberal Kritik, Princeton: Princeton University Press, 1989.

Ash-Shiddieqy, Teungku Muhammad Hasbi, Pedoman Zakat, Cet.III, Semarang: Pustaka Rizki Putra, 1999.

Bodeheimer, Edgar, Jurisprudence the Philosophy and Methode of the Law, Cambridge: Harvard University Press, 1973.

Golding, Martin P. dan William E. Edmundson, The Blackwell Guide to the Philoshophy of Law and Legal Theory, USA: Blacwell Publishing Ltd., 2005.

Gusfahmi, Pajak Menurut Syari'ah, Jakarta: Raja Grafindo Persada, 2007.

Hafiduddin, Didin, Zakat dalam Perekonomian Modern, Cet. I, Jakarta: Gema Insani Press, 2002.

Hafiduddin, Didin, "Sinergi Zakat dengan Pajak dalam Menyejahterakan Umat", makalah pada seminar di Dirjen Pajak, Jakarta 19 Agustus 2011

Kompilasi Hukum Ekonomi Syari'ah (KHES).

Mas'udi, Masdar Farid, Agama Keadilan: Risalah Zakat (Pajak) dalam Islam, cet 3, Jakarta: P3M, 1993.

Mas'udi, Masdar Farid, Islam dan Hak-hak Reproduksi Perempuan, Dialog Pemberdayaan, Jakarta: Rajawali Press, 2000.

Mas'udi, Masdar Farid, “Meletakkan Kembali Syari'at” dalam Jurnal Ulumul Qur'an Vol. VI. No. 31995.

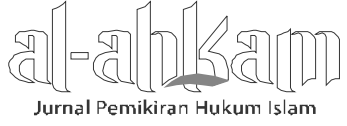

Volume 23, Nomor 2, Oktober 2013 
Mas'udi, Masdar Farid, Pajak Itu Zakat: Uang Allah untuk Kemaslahatan Rakyat Bandung: Mizan Media Utama, 2010.

Muhammad, Zakat Profesi; Wacana Pemikiran dalam Fiqih Kontemporer, Jakarta: Salemba Diniyah, 2002.

Nurudin Mhd. Ali: Zakat sebagai Instrumen dalam Kebijakan Fiskal, Jakarta: Raja Grafindo Persada, 2006.

Qomar, Mujamil, NU "Liberal" Dari Tradisionalisme Ahlusunnah ke Universalisme Islam, Bandung: Mizan Pustaka, 2002.

Raharjo, Satjipto, "Rekonstruksi Pemikiran Hukum di Era Reformasi", makalah dalam Seminar Menggugat Pemikiran Hukum Positivistik di Era Reformasi yang diselenggarakan Program Doktor Universitas Diponegoro Semarang, 2000 .

Raharjo, Satjipto, "Mengajarkan Keteraturan Menemukan Ketidakteraturan", Pidato Mengakhiri Jabatan Guru Besar Tetap pada Fakultas Hukum Universitas Diponegoro, Semarang, 15 Desember 2000.

Ramulyo, Muhammad Idris, Asas-asas Hukum Islam: Sejarah Timbul dan Berkembangnya Hukum Islam di Indonesia, Jakarta: Sinar Grafika, 1995.

Supena, Ilyas dan Darmuin, Manajemen Zakat, Semarang: Walisongo Press, 2009.

Sutiyoso, Bambang, Metode Penemuan Hukum, Yogyakarta: UII Press, 2006.

Syafei, Ermi Suhasti, "Mengoptimalkan Potensi Zakat" dalam Prosiding Simposium Nasional Ekonomi Islam, Yogyakarta: Pusat Pengkajian dan Pengembangan Ekonomi Islam (P3EI) UII, 2002.

UU No. 23 Tahun 2011 tentang Pengelolaan Zakat

Wacks, Raymond, Philosophy of Law: A Very Short Introduction, Oxford: Oxford University Press, 2006.

Wahid, Abdurrahman, Islam Kosmopolitan: Nilai-nilai Indonesia dan Transformasi Kebudayaan, Jakarta: The Wahid Institute, 2007. 